\title{
Promoting Outdoor Spaces Design features to Increase User Satisfaction in Residential Area. Duhok City as case Study
}

\author{
Layla M. Raswol \\ College of Engineering, Nawroz University, Kurdistan Region-Iraq
}

\begin{abstract}
The rapid development of the residential area in Duhok City and the new trend of housing policy towards high density and multifamily housing complexes affect the urban social life of the residents. The urban public open and green spaces in housing complexes create places for residents to come together and to strengthen their social networks. This research aims to investigate the outdoor space design approach in the new developed housing project (Avro city) as an example for high density multifamily housing complex due to its outdoor space design characteristics to identifying design features and elements that promote the quality of urban life and increase the user satisfaction in residential area. The researcher used qualitative data collection methodology using case study approach. The data collection method based on three sources namely the analytical study of the outdoor space design features from the available maps and site visiting, the on-Site observations of the residents, how they use the outdoor space, and the questionnaire survey results with the residents to measure their satisfaction about the outdoor space living environment. The findings of the research indicate that the design quality of the physical features such as landscape design, artificial water, landscape furniture, a proper pedestrian and greenery encourage people to use the outdoor space for social activities. Finally, the research provides guidelines for housing developers, urban designers and related governmental institutions to incorporate effective outdoor space design quality for successful urban living environment.
\end{abstract}

KEYWORDS : Residential, Outdoor Space, Social Interaction, Design Features, Case Study, Questionnaire.

\section{INTRODUCTION}

The public open spaces in the urban area play an important role in bringing residents to interact and communicate. They are the place for human social activities such as sport, meeting, recreation and leisure. The outdoor spaces surrounding residential blocks provide various kinds of space for people daily needs in addition to other social neighborhood activities. These activities have direct influence on the interaction between residents. The new trend in housing development in Duhok City is to support high density housing project by encouraging Investors to develop multifamily residential complex in the sub urban area of the city. Considering the outdoor space design quality in these projects is one of the crucial points that need to

Academic Journal of Nawroz University

(AJNU) Volume 7, No 3 (2018).

Received 10 April 2018;

Regular research paper : Published 20 July 2018

Corresponding author's e-mail : laylaraswol@nawroz.edu.krd Copyright (02018 Layla M. Raswol.

This is an open access article distributed under the Creative Commons Attribution License. be addressed to conserve the environment and improve the quality of residents living environment. The paper objective is to outline and investigate the main effective design features of outdoor space and identify the socially beneficial aspects of well-designed outdoor space at the aim to integrate them into design guidelines of the open and green space between residential buildings as attraction multi use open spaces to encourage the people to use it effectively and to promote the outdoor space living environment.

\section{Literature Review}

The paper will firstly define the key concepts of research topics which are the outdoor space design features and its role in resident's social life at the aim to define research objectives.

\subsection{Design Features of Outdoor Space}

Urban open spaces are publicly accessible designed and built for human activity and enjoyment. (Lynch 1981). Gehl 1987 divided outdoor activities into three types in the book of "Life between buildings" : necessary activity, optional activity and social activity. The optional activities include walking, playing, enjoying nature and fresh air. These may be affected by potential physical features of open and green space, which attract the residents to use it effectively. Social activities 
include various activities in public space where people would like to contribute. It includes greeting, meeting, children's play area, small-scale leisure activities. Gehl (1987) believes that spaces become meaningful and attractive when all activities of all types occur in combination. A livable and successful public space according to Gehl needs to have moving and stationary activities, space for walking and places for staying and spend time with the space (Gehl 1987). Francis 1987 points out that an attractive and functional open space can serve as space for children playing, greeting and conversation, communication activities as well as passive activities such as watching and hearing other people. Friedman (2010) added two other characteristics in term of scale and use. The open places must be small and consider pedestrian scale for more social interactions. According to Montgomery (1998) two main concepts are to be considered, diversity (Combinations of Activities) and vitality for successful urban open space. However, Carmona (2010) points out that public spaces can be considered as pedestrian movement spaces connecting the various uses social activities. Additional criteria are indicated by Marcus (2003), he argues that shared outdoor space can be an important component of the neighborhoods if it focused on the layout, circulation pattern, planting, landscape furniture of the outdoor space. In particular the design needs to focus on children needs since they comprise $80 \%$ of the user. As conclusion and according to project for public space (PPS 2015) there are four main indicators to measure successful public spaces : social usability, access and linkage, various uses activities, image and comfort to encourage people to go outside their home.

\subsection{The Role of Outdoor Design Features in Promoting Residential Social Life}

People activities play a significant role in designing and planning the public open spaces (Gehl 1987). Carmona 2010 argues that public space should be considered in social dimension. Studying the relationship between people and their environment is essential component of urban design to be considered in social dimension. The available activities and events within urban spaces can provide opportunities for people to engage in social relation (Carmona 2010). Considering environmental, physical and architectural features by designing the outdoor space can improve the sense of comfort, enhance social cohesion and encourage people to use the various spatial activities. The open and green space can give significant benefits to the neighborhood and community. Studies find out that having access to green space reduce stress, increase social interaction and enhance human wellbeing. The interconnection of people and nature or green space can enhance people daily lives and promote intellectual development, relaxation, physical and emotional wellbeing (Kellert
2005). Therefore, creating potential outdoor environment for particular attractive activities within the space through greenery, creating attractive physical features such as comfortable sitting places, artificial waters contribute to increase user satisfaction about the living environment in residential area.

\section{Methodology}

After reviewing relevant literature, the research uses qualitative data collection methodology using case study approach in the city of Duhok focusing on the new developed residential area in Avro city as a useful case study for high density multifamily housing complex based on its outdoor space design characteristics, which is relevance for the research objectives. The research data collection based on different sources namely the analytical study of the design features of the outdoor space based on the available data, plans and site visiting, the on-Site observations of the residents, how they use the outdoor space and the questionnaire survey to measure their satisfaction about the outdoor living environment. The results of the spatial elements will be examined by three main variables developed from literature review : accessibility and connectivity, spatial form and functions variety, landscape design quality to identify the effect of outdoor space design on resident's satisfaction.

\section{Case Study Area}

Duhok City, one of the main three cities in Iraqi Kurdistan, has expanded enormously in the last few decades. This process of expansion has accompanied with planning and development of new settlements in the suburban area of the city. The new trend in housing development is to increase density and quality of the housing environment. The case study of this research represents the new developed residential area that has been developed after 2006. The selection of this project was due to its outdoor space design quality, which is relevance to research objectives and could be an example for future housing projects.

\subsection{Avro city housing project}

Avro city is a mass residential complex in Duhok city. It locates in the west of Dohuk and it is $6 \mathrm{~km}$ far of the center of Dohuk. The project was started in 2007 and completed in 2014, and the total area of the residential project is about 100 ha of land. It is located near to University of Duhok in the suburban area near Duhok Zakho highway (Fig 1). It neighbors the Tenahi neighborhood, which was developed in the 1990. Avro city project consist of different size and types of apartment building and different size of villas in the project. The population size of Avro city housing complex according to the directorate of statistic in Duhok city is 20,000 in 2016. The complex includes social services such as police station, kindergarten, 
nurseries, schools, grocery stores, health center as well as a fire department.

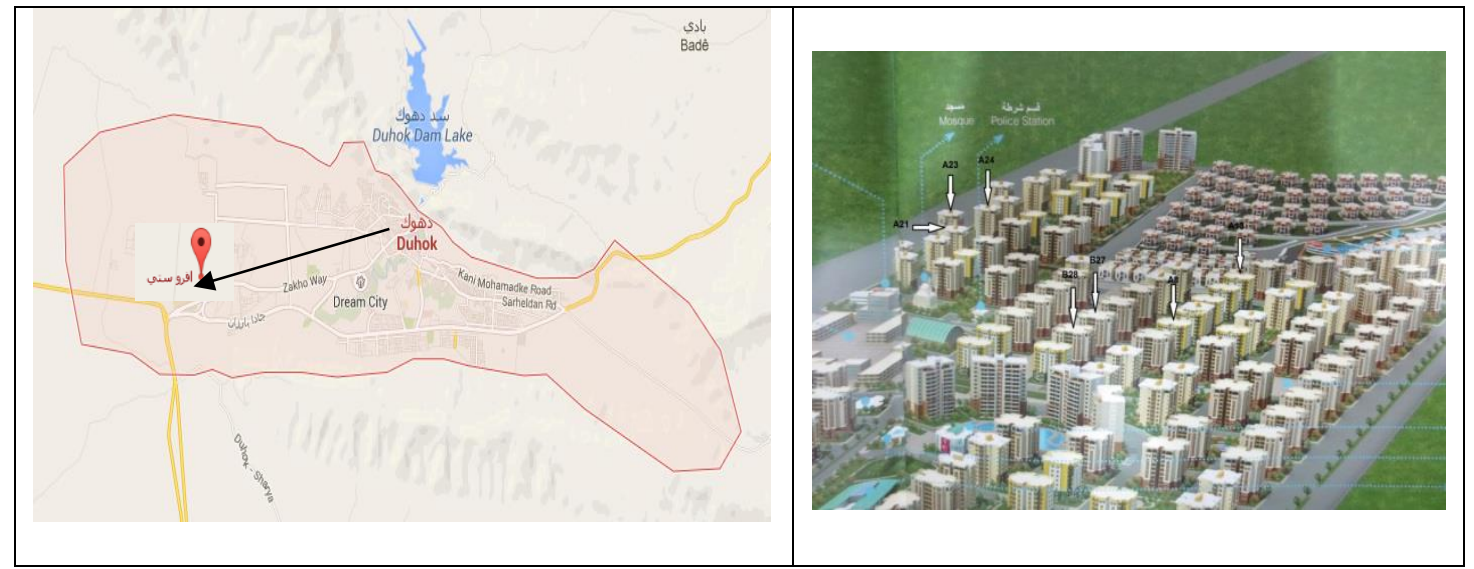

Fig (1) : Location of Avro city in Duhok. Source Google earth and project directory 2017

\section{Results and discussion}

The project of Avro city has developed to encourage social-cultural interaction between people by providing good spatial elements and social services such as constructing green area and walkways around each apartment building and villas with space of various activities for the resident to enjoy their time (The director of the project 2017). The research finds out from onsite observation that there are effective design features that influence the resident's behaviors and provide opportunity for urban social life :

\subsection{Access, connectivity and walkability}

The shared open space between the housing is pedestrian-oriented. The street connectivity with the services and facilities is well constructed. Car parking places are integrated in housing layout Comfortable pathways link the open public open space one to each other and connected to residential buildings the residents could reach the outdoor space from their home by less than a 5-minute comfortable walk as the distance between them had been designed as short as possible Figure 2.

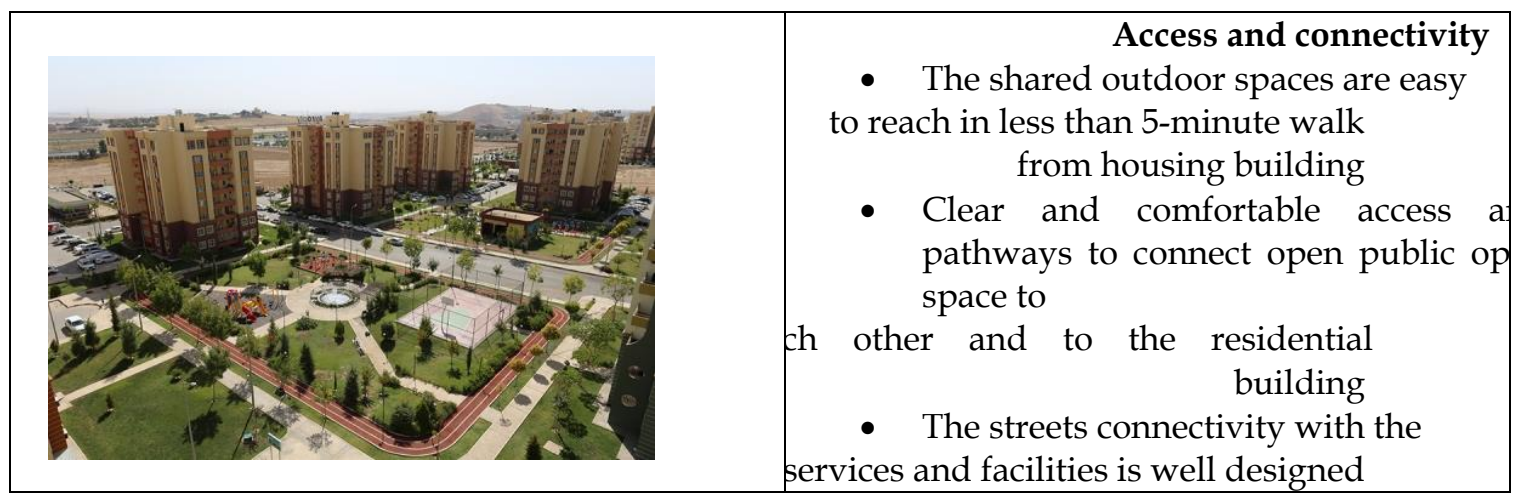

Fig (2) : Finding of the Acceses and connectivity. Source : Researcher 2018

According to observation finding the level of walkability in the area is high, because of the safe pathways and sidewalks provided for the resident in the whole neighborhood, as well they took in consideration the equity aspect such as disable people, children and seniors. Regarding the safety, the project has provided a good quality of walkable pedestrians and footpaths (Fig 3). The sidewalks are landscaped include buffer for sitting places. Trees and shade benches create a pleasant image. 


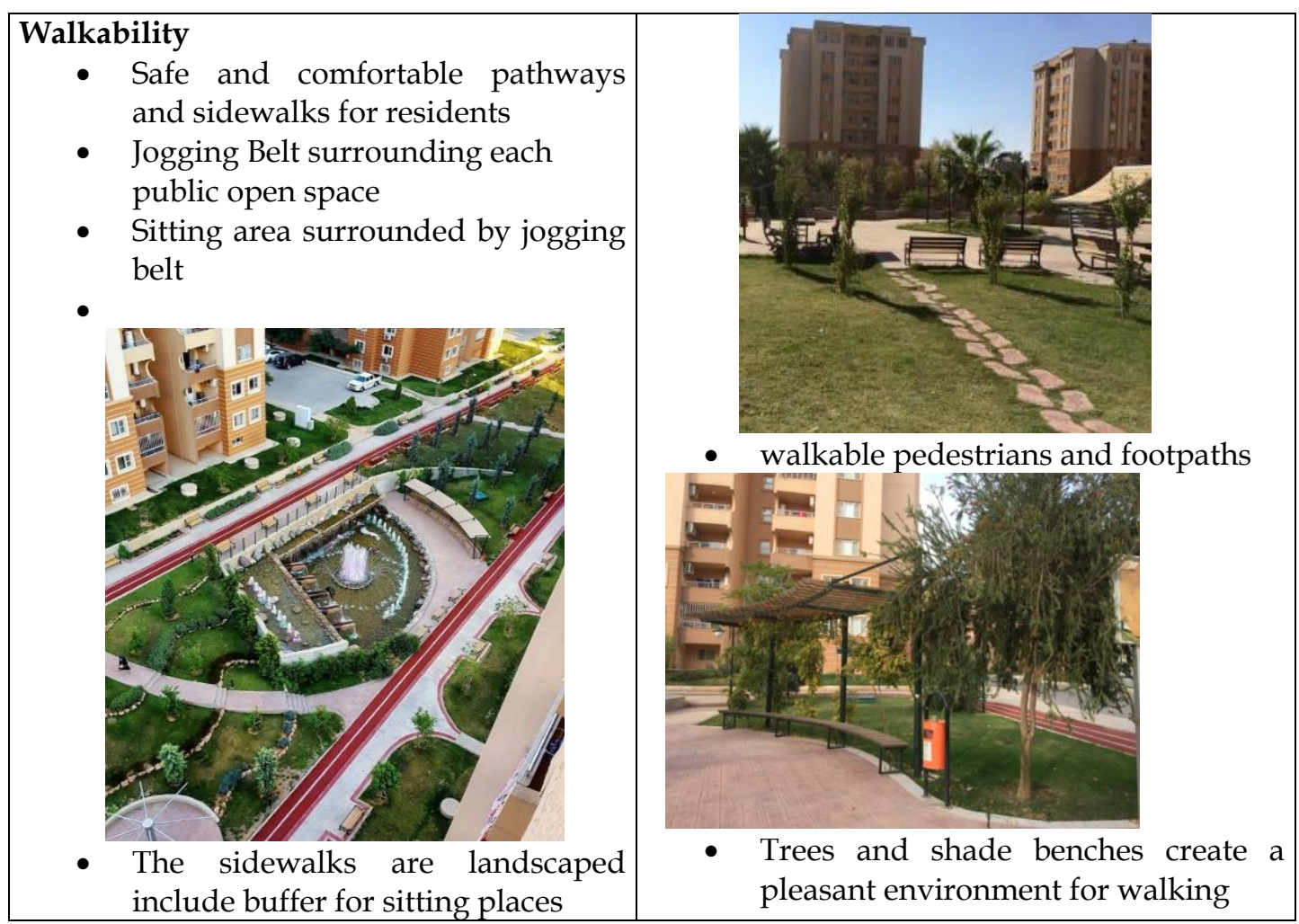

Fig (3) : Finding of walkability in Avro city neighborhood, source Researcher 2018

\subsection{Spatial form and functions variety}

Avro city is composed of various residential Buildings types, including, mid, high rise free standing multifamily housing units, and single-family villas, which are organized in a grid system with sufficient multi uses outdoor space landscaping between the building. Each housing group has its public space connecting gardens and children's playground, leisure and sport facilities. (Fig 4, 5)

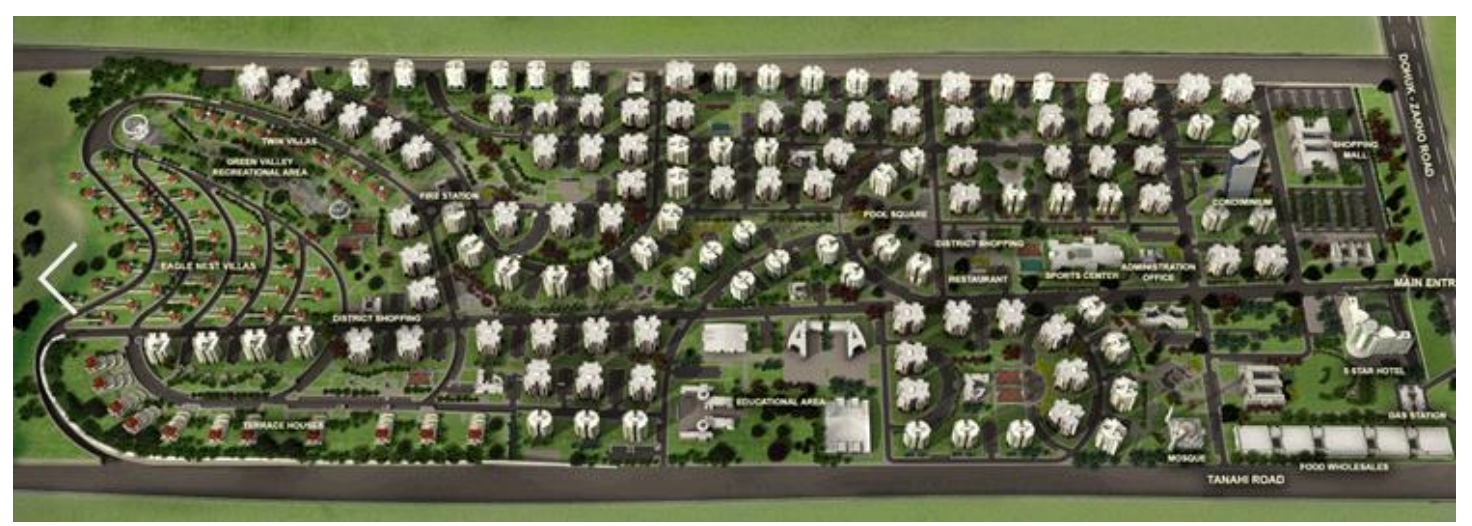

Fig 4 : Site plan of Avro city, based on project directory office map 2017 


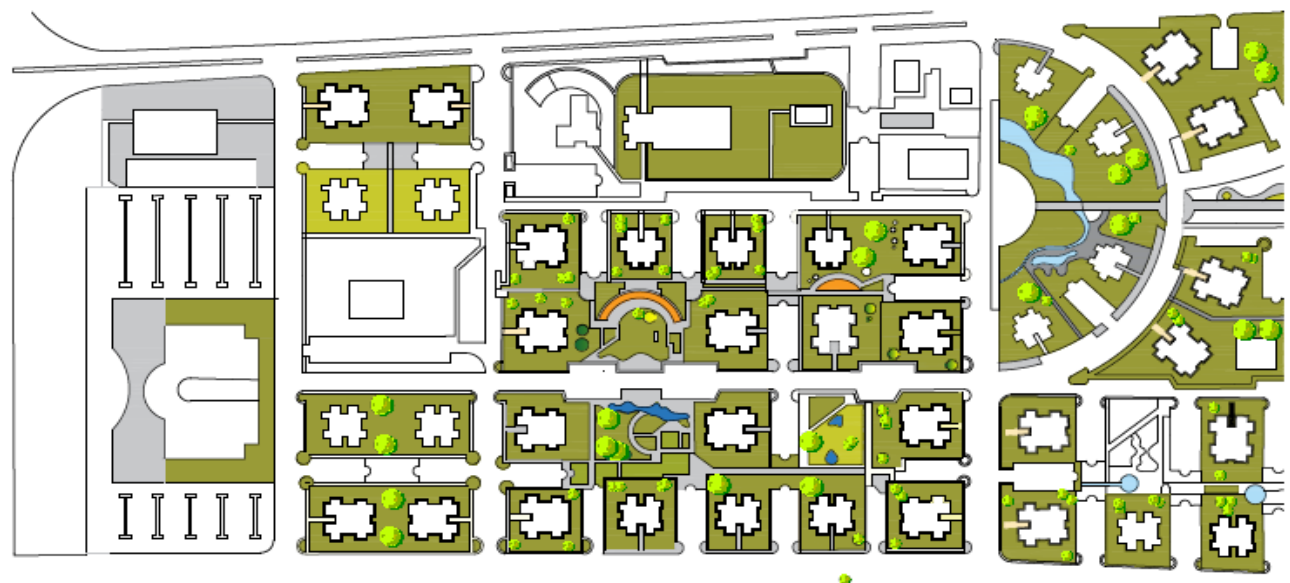

Fig (5) : Architectural layout of Avro city, based on project directory office map 2017

The outdoor shared space designed to be the joint point of public living with various activities and leisure places consist of green area artificial water fountain children play ground, sport area for youth, fitness area, sitting area surrounded by jogging belt. Different space combination creates a relatively comfortable living environment and provides opportunity. The designed space between Buildings with greenery and mix use activities increases the sense of enclosure and vitality. The clear paths, nodes and edges add valuable identity to the neighborhood (Fig 6).

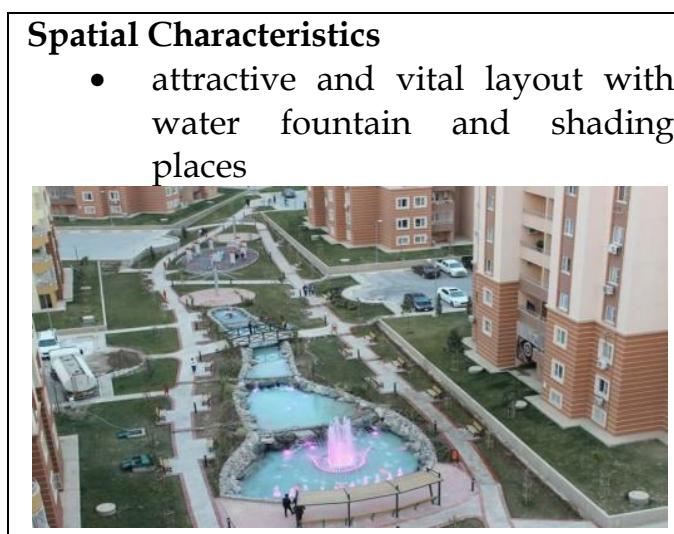

- The clear paths, nodes and edges add valuable identity to the neighborhood

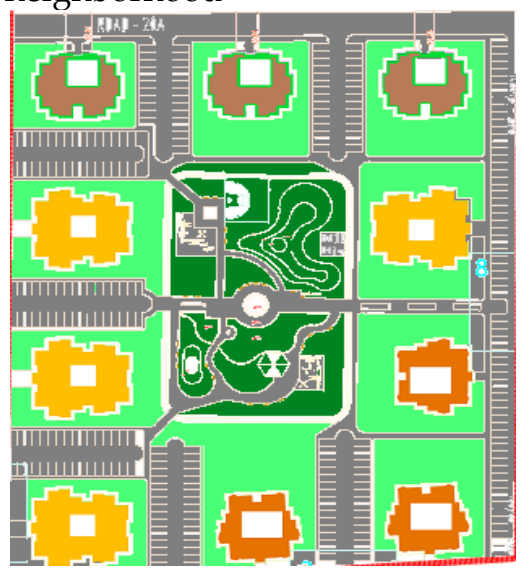

- The edged outdoor space increase sense of enclosure, comfort and vitality

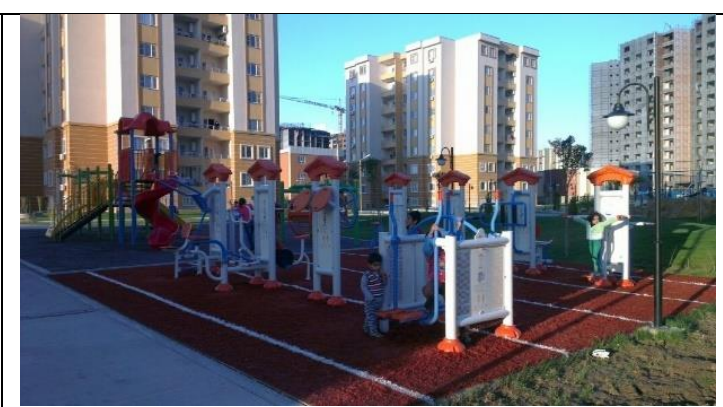

- Combination of mix uses activities

- Well-designed spaces for all age groups

- The designed space between Buildings with greenery and mix use activities increases the sense of enclosure and vitality

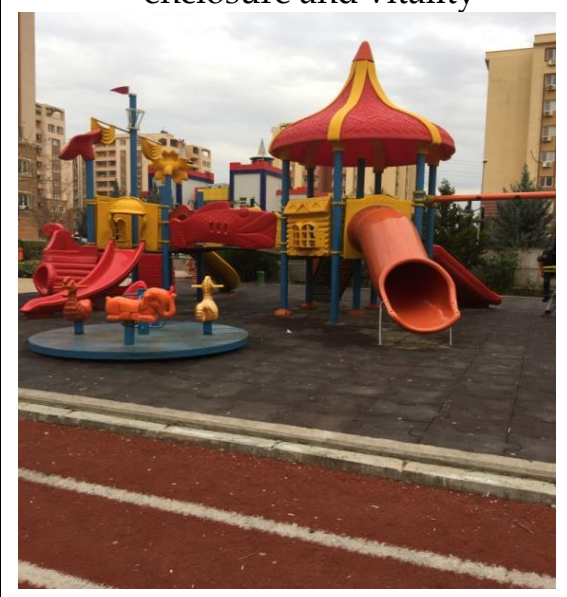

- Safe children play yard

Fig 6 : Finding of the spatial variety and functions. Source researcher 2018 


\subsection{Landscape design and quality}

The main component of Avro city is the design quality of the landscape and greening. It is a peaceful, enjoyable and safe area for the people to spend time. Each apartment building is surrounded with local green area in addition to semi-public parks that have been provided for all the residents. The various artificial water and landscape furniture give a pleasant view to the neighborhood also it contributes in improving the air quality and creates a healthy life style in the area. The diversity in landscape features adds visual richness and valuable character to the area. The variety of landscape typologies within uses spaces increase the opportunities for engaging the residents in physical activities (Fig 7)

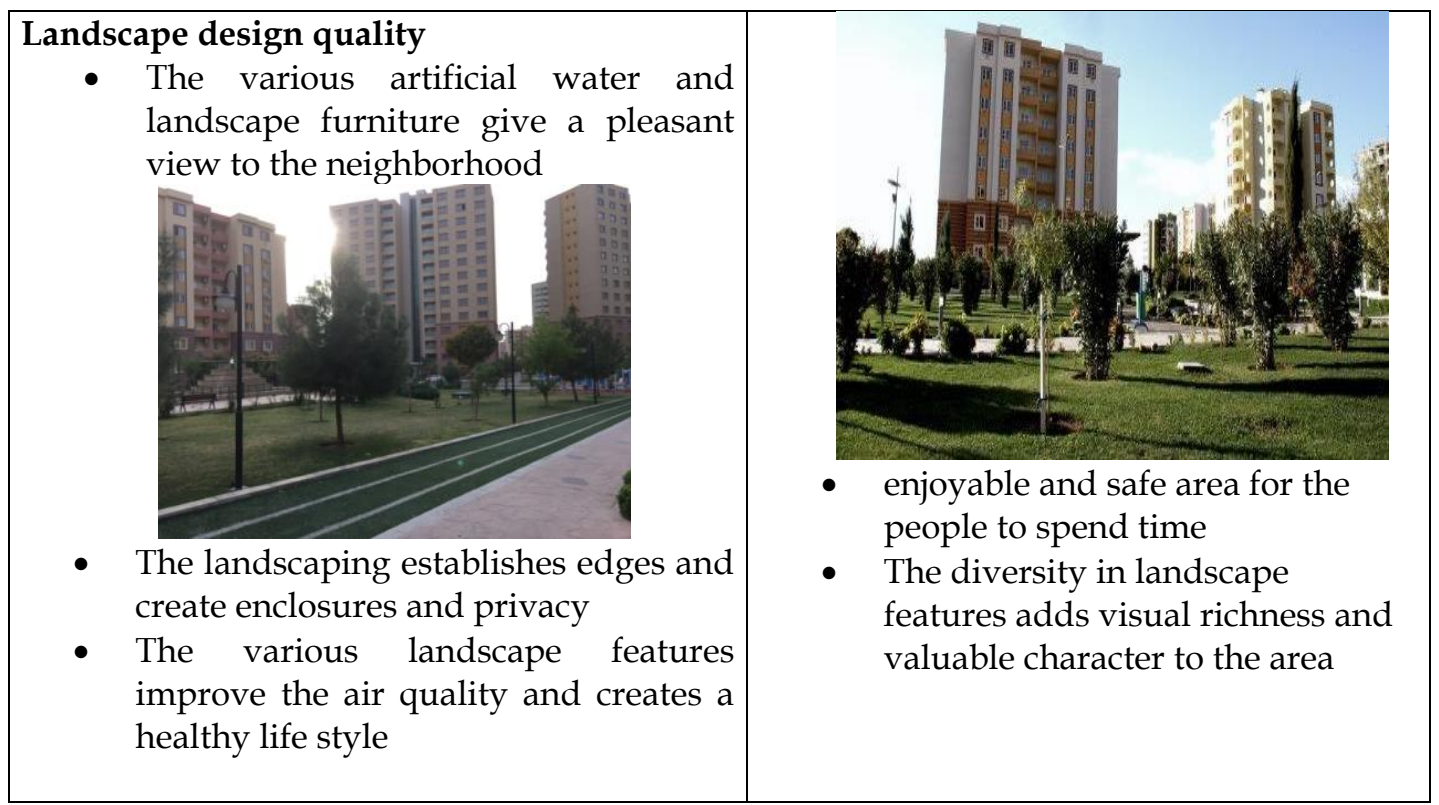

Fig (7) : Finding of Landscape Design Source researcher 2018

\section{Results and discussion of the questionnaire 6.1. User satisfaction}

The questionnaire was organized to measure resident's satisfaction and their perception about the outdoor living environment and how they use the outdoor space. 50 questionnaires were distributed randomly to the users of the outdoor spaces all over the neighborhood. The respondents were $40 \%$ male and $60 \%$ female. Table 1 shows the results of the questionnaire. 
Table (1) : shows summary of the finding of the questionnaire used in the research. (Researcher)

\begin{tabular}{|c|c|c|c|c|}
\hline \multicolumn{5}{|c|}{ Effect of Design Quality on User satisfaction } \\
\hline No. & Statement & Agree & Neutral & Disagree \\
\hline & Access and connectivity & & & \\
\hline 1. & $\begin{array}{l}\text { The outdoor space location within } \\
\text { neighborhood area suitable for the residents }\end{array}$ & $74 \%$ & $26 \%$ & 0 \\
\hline 2 & The outdoor space easy to access from home & $64 \%$ & $32 \%$ & $4 \%$ \\
\hline 3 & $\begin{array}{c}\text { The main gate to outdoor space from home is } \\
\text { reasonable }\end{array}$ & $64 \%$ & $34 \%$ & $2 \%$ \\
\hline 4 & $\begin{array}{l}\text { The transportation network makes an easy } \\
\text { access to the outdoor space activity }\end{array}$ & $50 \%$ & $44 \%$ & $6 \%$ \\
\hline 5 & $\begin{array}{l}\text { The movement and pedestrian flow in the } \\
\text { neighborhood is well designed and safe for } \\
\text { the user. }\end{array}$ & $48 \%$ & $40 \%$ & $12 \%$ \\
\hline \multicolumn{5}{|c|}{ Spatial Form, functions variety } \\
\hline 6 & $\begin{array}{l}\text { The design of open spaces within the } \\
\text { neighborhood is encouraging to spend time } \\
\text { there }\end{array}$ & $68 \%$ & $30 \%$ & $2 \%$ \\
\hline 7 & $\begin{array}{l}\text { The various activities are sufficient and } \\
\text { useable }\end{array}$ & $70 \%$ & $30 \%$ & $\mathbf{0}$ \\
\hline 8 & $\begin{array}{c}\text { The outdoor space environment is attractive } \\
\text { and suitable }\end{array}$ & $60 \%$ & $34 \%$ & $6 \%$ \\
\hline 9 & The kids have enough place to play & $52 \%$ & $44 \%$ & $4 \%$ \\
\hline 10 & There is enough space for various activities & $52 \%$ & $40 \%$ & $8 \%$ \\
\hline \multicolumn{5}{|c|}{ Landscape design quality } \\
\hline 10 & $\begin{array}{l}\text { The landscape design space provide } \\
\text { opportunity to go out of the home }\end{array}$ & $58 \%$ & $38 \%$ & $4 \%$ \\
\hline 11 & $\begin{array}{c}\text { The landscape design is attractive and } \\
\text { enjoyable }\end{array}$ & $68 \%$ & $32 \%$ & 0 \\
\hline 12 & $\begin{array}{c}\text { The maintenance of the outdoor space is } \\
\text { sufficient }\end{array}$ & $54 \%$ & $26 \%$ & $20 \%$ \\
\hline 13 & $\begin{array}{c}\text { The quality of the landscape contributes to } \\
\text { improve the } \\
\text { air quality }\end{array}$ & $60 \%$ & $36 \%$ & $4 \%$ \\
\hline 14 & There is enough place for sitting and meeting & $34 \%$ & $50 \%$ & $14 \%$ \\
\hline 15 & $\begin{array}{l}\text { The landscape furniture is sufficient } \\
\text { (benches, shading, water fountain) }\end{array}$ & $34 \%$ & $46 \%$ & $20 \%$ \\
\hline
\end{tabular}

\subsubsection{Access and connectivity}

The majority of the residents ( $74 \%$ agreed) are satisfied with the location of the public open space and its access to the residential buildings. $64 \%$ agreed that the outdoor space is easy to access from their home and the main gate is reasonable. Half of the respondents are satisfied with accessibility. Only $12 \%$ are not satisfied with movement and pedestrian flow in the neighborhood. (Fig 8) 


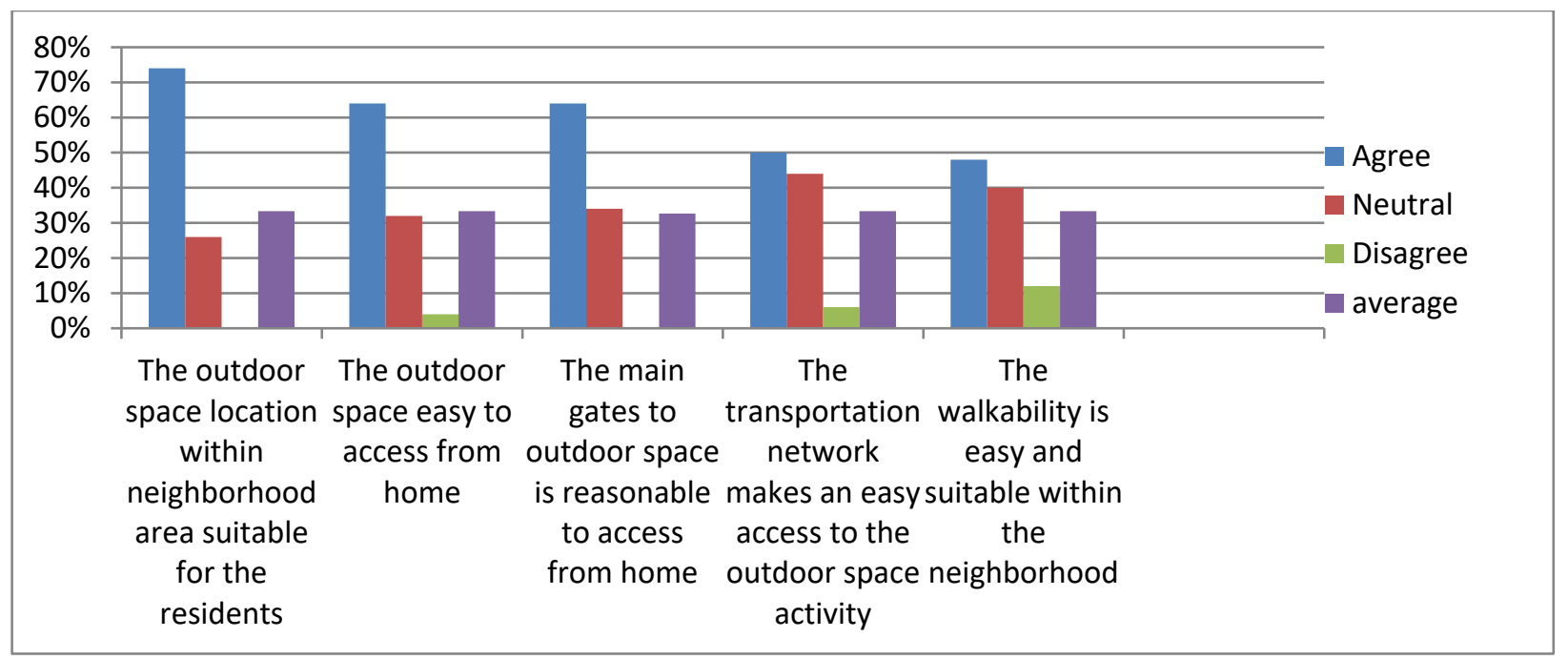

Fig (8) : User Satisfaction about access and connectivity. Source researcher November 2017

\subsubsection{Spatial Form and function}

The interview results confirmed that respondents are mostly satisfied with the outdoor environment and enjoy the various activities. $68 \%$ agreed and $30 \%$ were neutral with the encouraging spatial form and functions of the open space activities to spend time there. $70 \%$ agreed that the various activities are sufficient and useable. More than $50 \%$ of the respondents are satisfied with children play area and there is enough place for various activities. (Fig 8)

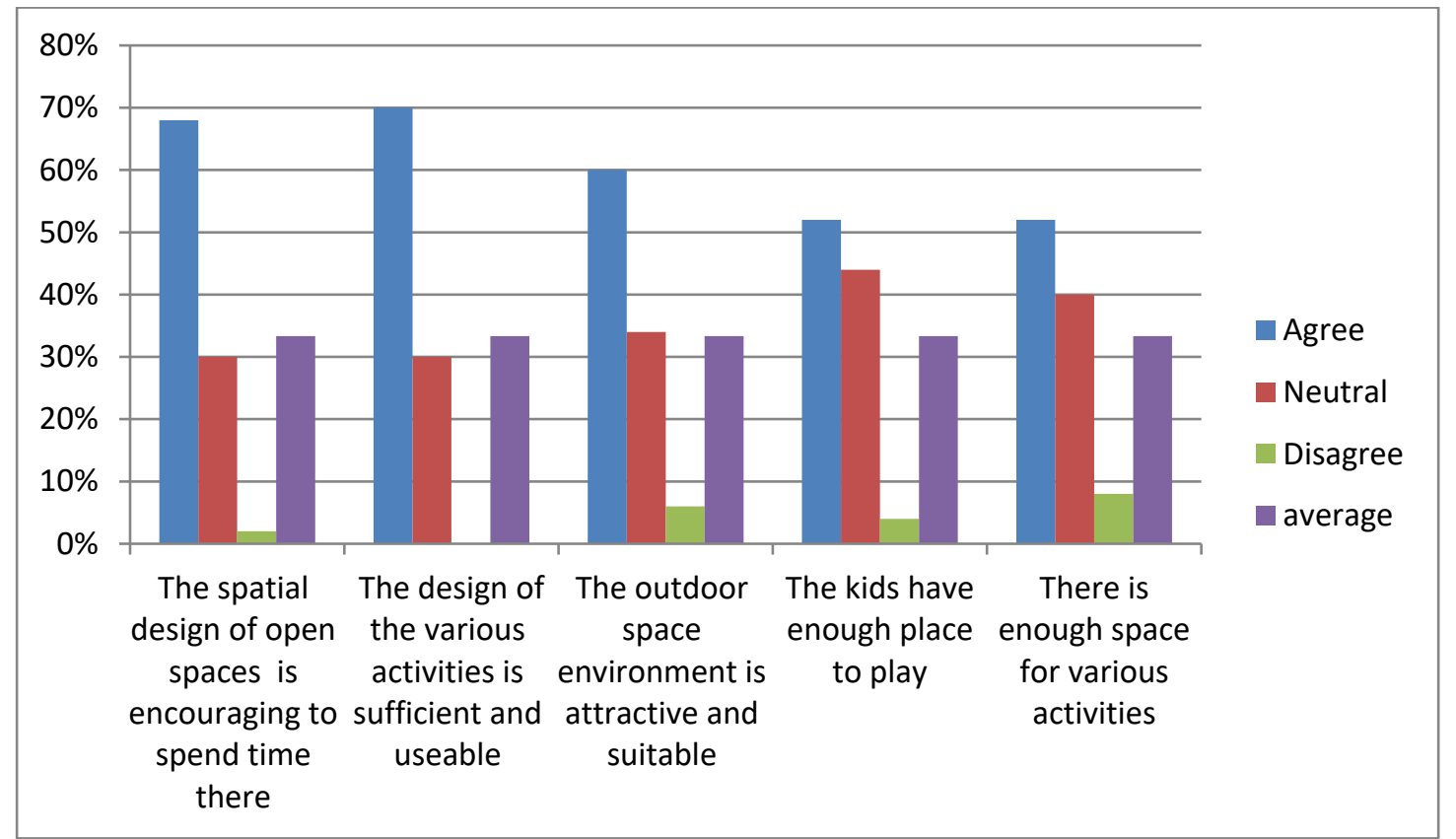

Fig (8) : User Satisfaction about Spatial form and functions. Source researcher November 2017

\subsubsection{Landscape design quality}

The majority of the respondents (58\% agreed) are satisfied with landscape design and quality and said that its well designed and encouraging to spend time there. $68 \%$ agreed that landscape is attractive and enjoyable. More than $50 \%$ agreed that the landscape maintenance is sufficient. Half of the respondents agreed that the landscape contribute to improve air quality. $50 \%$ were neutral that there is enough place for sitting and meeting. Only 20\% disagreed that the landscape furniture sufficient. (Fig 9) 


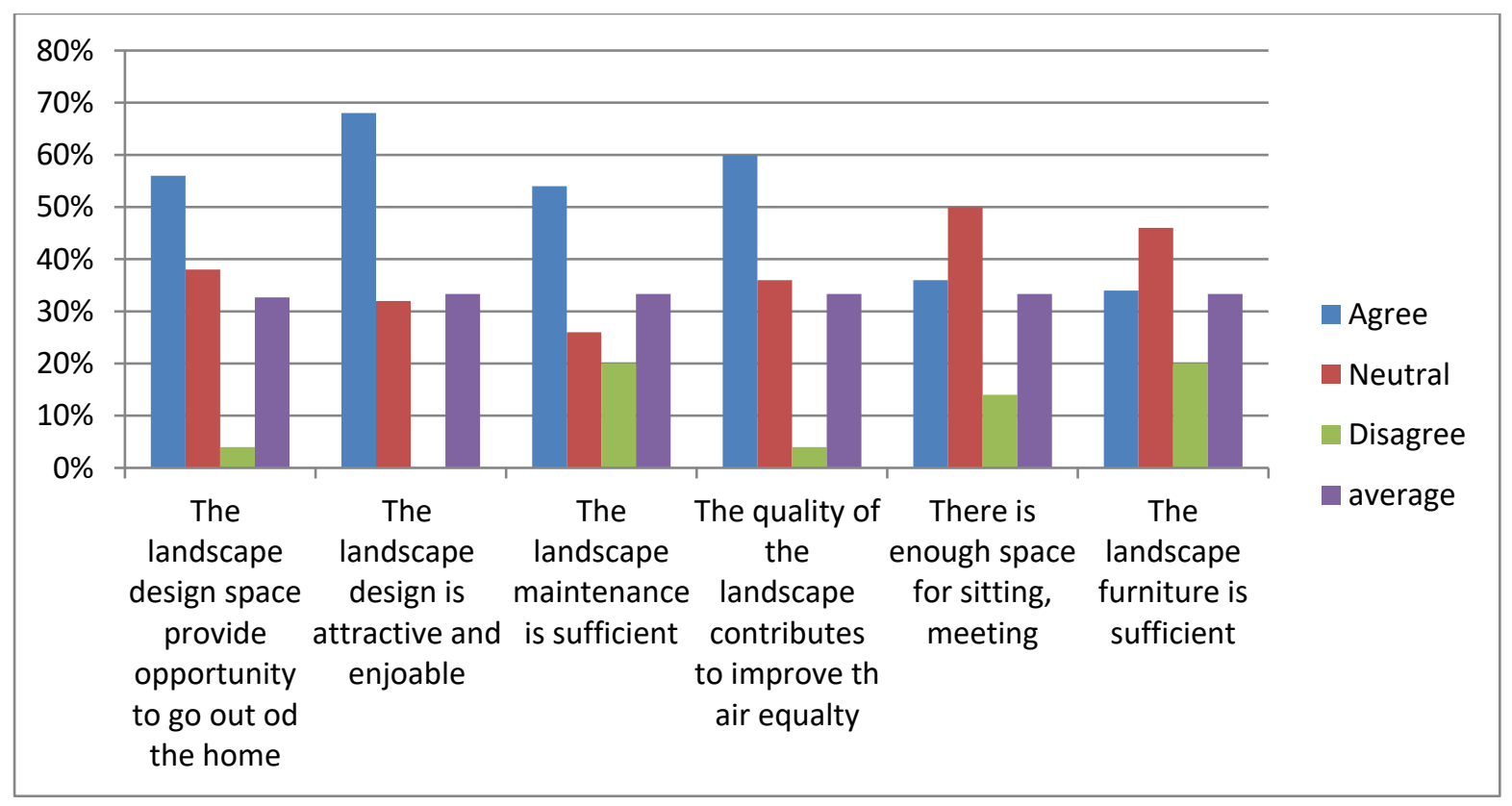

Fig (9) : User Satisfaction about Spatial form and functions. Source researcher November 2017

\section{Conclusion \& Recommendations}

Public outdoor space in residential areas plays an important role in the way a space is perceived and how effectively it becomes a part of the housing area by providing useable and comfortable spaces for the various activities people needs outside their home. The main consideration in residential outdoor space design is the basic function of the areas to meet different people 's needs such as quite space for elder people, entertainment place for children. Well-designed features could be added to enrich the urban landscape to attract the people to go outside their homes. The results indicated that promoting the quality of public outdoor space surrounding the residential area will encourage people to participate in the various designed activities. It is important to bring character and life to the neighborhood by improving the design quality of the open and green space of the residential area and provide opportunities for leisure and social activities, for instance enhancing the physical health and wellbeing by providing places for relax, sport exercising and contact with nature. The research confirmed that there are certain outdoor design characteristics that impact positively on the resident's satisfaction and enhance social life environment and human wellbeing, including Landscape greenery, safe and distinct paths for movement and pedestrians, spatial variety of uses and comfortable environment. These design quality of the outdoor spaces encourages the residents to use it at different times and seasons therefore the research recommends that the housing developers and related decision makers should consider the following points in future housing projects :

\section{Refences}

1. Outdoor Spaces should be designed to accommodate uses by diverse groups and at different times.

2. Outdoor Spaces should contain functionally defined areas for all age levels and can be modified for use by specific groups or the community.

3. Outdoor Spaces should be easy to access connecting the various space activities and pedestrian oriented with comfortable side walk

4. The landscape furniture and green area should be considered such as comfortable sitting places, trees, water fountain.... etc.

5. Outdoor Spaces should be designed in consideration of the environmental, socio cultural as well as identity of the place.

6. Refereces

7. Carmona, M., Tiesdell, S., Heath,T., and Oct., (2010), "public places Urban spaces: The

8. dimensions of urban design", Architectural press, UK.

9. Francis M (1987) Urban Open Space, Advanced in Environment, Behavior and Design (Vol. I). Environmental Design Research Association, New York and London

10. Friedmann, J., (2010), Place and Place-Making in Cities : A Global Perspective", Planning

11. Theory \& Practice

12. Gehl, 1987 Life between Buildings, The Danish Architectural Press, Copenhagen

13. Kellert, S. R. 2005, Building for life : Designing and understanding the Human- nature connection, Island press. 
14. Lynch, K. (1981), A theory of good city form, MIT Press, Cambridge.

15. Marcus, C. C., (2003), Shared Outdoor Space and Community Life, placesjournal.org

16. Montgomery, J., (1998), "Making a city : Urbanity, Vitality and Urban Design", Journal of Urban Design
17. Project for Public Spaces (2015), from Project for Public Spaces, http : / /www.pps.org 